\title{
Negotiating Employee Contracts Case Study Review Negotiations and Conflict Resolution
}

\author{
Kwesi Atta Sakyi ${ }^{1}$, Esnart Mwaba Tayali ${ }^{2}$, Godffrey Kapasa Mweshi ${ }^{3}$, David Musona ${ }^{4}$ \\ ${ }^{1}$ Directorate of Research Consultancy and Innovation, ZCAS University, Lusaka, Zambia \\ ${ }^{2}$ Department of Work Employment and Organization, University of Strathclyde, Glasgow, Scotland \\ ${ }^{3}$ Department of Social Sciences, ZCAS University, Lusaka, Zambia \\ ${ }^{4}$ Department of Accounting and Finance, ZCAS University, Lusaka, Zambia
}

Email address:

kwesiattasakyi449@gmail.com (K. A. Sakyi),kwesi.sakyi@zcas.edu.zm (K. A. Sakyi), estayali@gmail.com (E. M. Tayali), Dr.Godffrey.Mweshi@zcas.edu.zm (G.K.Mweshi),david.musona@zcas.edu.zm (D. Musona)

\section{To cite this article:}

Kwesi Atta Sakyi, Esnart Mwaba Tayali, Godffrey Kapasa Mweshi, David Musona. Negotiating Employee Contracts Case Study Review Negotiations and Conflict Resolution. Journal of Human Resource Management. Vol. 8, No. 3, 2020, pp. 139-145.

doi: $10.11648 /$ j.jhrm.201200803.14

Received: April 27, 2020; Accepted: June 3, 2020; Published: June 23, 2020

\begin{abstract}
This paper is a review of a case study in human resource management with a slant towards the legal aspect of contract of employment and renegotiation of contracts. As none of the authors is a lawyer, the paper is reviewed from the managerial rather than from the legal point of view. Cindy is the lady employee in question who worked for a company for many years and never thought that a time would come when her employer would transfer her to a far off and forlorn place in the midst of nowhere. Her relocation puts her off and she thought she had been unfairly treated by her employer. In the analysis of the issues at stake in the scenario, the authors came to the conclusion that both Cindy and her employers had merit in their case should they go to court for adjudication and pronouncement of a verdict. Cindy on her part did not follow due process at the onset to ask questions about her job. It seemed also that her employers on their part did not do full disclosure about the nature of the job and the need to relocate staff when necessary. The authors decided to use the exploratory approach methodology in this case study review as there was not much information in the scenario to go by. The case study method has been found to be a suitable method of research that enables a phenomenon to be examined closely at a micro level so that knowledge from a small sample can be extended to cover generalizations of all similar cases, using the deductive and inductive approaches. Therefore the authors made some assumptions and used the deductive and inductive approach to arrive at logical conclusions. This article is therefore a narrative article and a commentary that does not include any primary research material. Readers are free to come to their own conclusions on the merit of the case as the main objective of the authors of this article is to generate knowledge for academic discourse. Human Resource practitioners and theoreticians will hopefully find the article stimulating food for thought and pertinent to their work.
\end{abstract}

Keywords: Employment Contract, Negotiations, Attributes of Valid Contract, Employer-Employee Relations, Full Disclosure, Sources of Power, Psychological Contract, Perception, Contract Re-negotiation

\section{Introduction}

Poem on Cindy

Employer employs and deploys,

Employee complies and cries-

Foul! Foul! Job a ruse,

Not enough dough to use,

Rope-a-dope,
A ploy with entrapment, a decoy

But remuneration full value received with much ado!

Employer denies and decries charges,

Blame it on psychological contract,

It's in nature of the game,

On balance of probabilities,

It's a zero sum game,

The die is heavily loaded,

Always loaded in favour of power calculus, 
Employer stands tall a winner,

Cindy stands small a loser,

Cindy Lopez, Cindy Loper, Cinderella,

In cinders!

Might is right; the vulnerable stands vanquished!

The case study in question is about Cindy who had had a job with her employer for a considerable length of time (though the scenario was silent on how long ago before the decision four years ago to transfer her to a forlorn location in the desert), and getting to the expiry of the four year contract, there was no more contract for her as the economy was in recession, and she seemed to be in a panic mode, desperately looking for a job in an economy which had recorded dismal performance due to the sub-prime mortgage and financial crisis, and the impact of the Corona Virus (COVID-19) pandemic. Cindy in her panic decided to sell her house at a loss and also get rid of her car and furniture. The article reviews various concepts such as sources of power, motivation, non-negotiable contracts, and psychological contracts.

Not much information is provided in the scenario for one to go by, so these authors made some assumptions and resorted to spotting out the gaps in the scenario. The approach to the article is that of engaging in a critical analysis and using secondary data sources for in-text referencing and substantiation of points made.

The objective of the article is to answer the questions posed in this case study as well as to use deductive and inductive logic to make inferences and pertinent observations regarding some of the lacunas in the case. The authors don on the hat of a consultant and also that of an amicus curiae or friend of the court. Despite the fact that the authors have no formal legal training, they used their experience and brush with the law from chats they had had with their legal friends to craft this article which was originally an assignment they did for their MBA programme. However, from a bit of legal exposure from talking to their legal colleagues and students, they tried to be as critical as possible, as well as act like pocket lawyers.

\section{Theoretical Review}

Identification of Successful and Unsuccessful Aspects of the Negotiation

Every type of contract has aspects such as capacity to enter into legal relationships which denies minors or those under 18 years of age, prisoners, mentally unstable people, and people not in full control of their mental faculties, either drunk or under strong medication or sedation, and in some cases, morons, imbeciles, and people under duress or threatfrom contract agreements [11, 19].

All these conditions will render a contract null and void and non sequitor or invalid if any one of them is present. A contract can either be in written form or it can be oral, informal and treated as a gentlemanly-binding agreement deemed more valuable if the parties to it are people of high moral fibre and honourable in demeanour. A contract should have an offer to treat, acceptance, capacity to enter into legal relationships, consideration and locus standi. If these elements or ingredients are not present, the contract is invalid. Other ingredients are certainty, and intention to create legal relations [15, 16, 19, 24, 25].

A contract should also be agreed to by someone who understands the language used; if not, they should hire an interpreter to translate for them. A valid contract should be signed in a proper abode such as a home, a court, and an office and not in a tavern or drinking bar. First, there is an offerer and offeree. In this case study, Cindy is the offeree and her employer is the offerer. There is first an invitation to treat followed by an offer and acceptance [15, 16, 19, 24, 25].

When Cindy was offered the letter of employment with the contract terms given to her, she should have read between the lines to understand the terms of the contract, including the spirit and letter of the contract to know what was in store for her as every contract has explicit and implicit nuances which only legal luminaries can spot and interpret $[15,16,19,24$, 25].

According to Francis (2019), the terms of a written contract of employment should contain certainty or specific details such as names of Employer and Employee, dates of starting and completion of the contract, names of the witnesses to the deed, job title, job location, duties and responsibilities, reporting lines, pay amount and intervals of payment, leave days, terminal benefits, notice for termination on both sides, working hours, method of determination of termination, severance pay, disciplinary procedures, grievance procedures, and rights and privileges, among others, and subject to state or federal laws. Other aspects could be found in the Employee Handbook during induction training or orientation conducted by the employer $[6,15,16$, 19, 24, 25].

Cindy could have sought second opinion from her lawyers or a Human Resource Consultant whether the terms and conditions in her contract conformed to her State and Federal Labour Laws and also she should have sought clarification on the employment terms and conditions. An offer requires acceptance. According to $[2,5]$ employment law varies from state to state which is true for federal countries such as the USA, India, Nigeria, Canada, and Australia where they have plurality of laws.

According to Gospel \& Palmer (1993) cited in [23] employment is defined as a political, economic or social relationship whereby employees provide required services or labour in exchange for rewards from their employer which rewards can be deemed as economic, social, political, or psychological.

Cindy should not have been too eager to accept the offer lock, stock and barrel as the offer was not cast in stone. She should have sought variations to some parts of the contract such as provision for renewal at the expiry date, variation to the notice to be given each party before termination, room for extension of the contract, among other terms. Cindy should have asked many questions at the beginning and should have negotiated for some provisos such as demanding for some 
inconvenience allowances, severance pay and gratuity, and a lower minimum stay at her new relocated place as it stated a minimum of three years. Many employees lack knowledge of their rights under the labour law and human rights law.

Cindy erred somehow when one year into her contract, she was offered a new job by another firm and she declined the offer in order to keep her word and honour. She should have given the minimum notice in her contract of employment which would have been say a month or three months' notice, and explained to her new employers, who would have waited for her to wind up with the old employer. That job offer was very lucrative and timely. It is often said that opportunity strikes but once. It is also said that the devil you know is better than the angel you do not know. Therefore Cindy might have been on the horns of a dilemma.

She was torn between and betwixt, between the deep blue sea on the one hand and the devil on the other hand. She should have jumped ship without honouring her word as her employers did not show consideration when transferring her to that forlorn and God-forsaken place. Or well, who knows, her employers could have been preparing her for bigger things to come. However, experience proves that in most cases, employers pursue their own selfish interests by using and dumping their employees at will. Some engage in employee bullying by cutting employee salaries with the flimsiest of excuses when it suits them well, and others demote and dilute their employees' jobs, despite the fact that these acts constitute contract infringements and miscarriage of justice. Some employers engage in contract creep or contract debasement when it suits them, especially after they had employed someone and found them vulnerable [20].

Others engage in casualization of labour by giving short term contracts as a way of maximizing profit without having any humanitarian feeling for those who are exploited by casualization of their labour. Casual labour or the interns and temporary workers (temps) in the commercial banks in Zambia are often given extremely hazardous targets to achieve like bringing in the equivalent of about 5 million dollars in a month in new client savings.

Such young temps work under extreme stress and pressure to meet those seemingly impossible targets, and in the end, they are jettisoned by their Shylock employers after milking them dry. Even though the government of Zambia has declared casualization illegal, the high rates of poverty and unemployment among the youth in Zambia have made casualization a lucrative practice and proposition which is covertly done in many institutions in Zambia because oversight, inspection and regulatory bodies are weak, corrupt, inefficient, and highly politicized.

It is most often the case that there is information asymmetry, incomplete contracts, and worker bullying and exploitation because workers cannot enforce their rights due to the high cost of legal fees and the time-consuming nature of legal wrangles in the already overburdened courts of law. Employees are normally bullied or exploited where they have no trade unions or professional bodies to protect their interests. Trade Unions offer security and protection due to the sheer size of their numbers which intimidate employers $[7,9,12]$. Cindy in trying to honour her word in her letter of acceptance was doing the morally right thing but not in those contexts where you think your employer lacks empathy and transparency.

When the spirit and letter of the contract was considered, it was within her rights as a woman to have asked for more liberal terms in relation to her transfer. We shall assume that Cindy was not married, that she had no child, that she had not worked before, that she did not look before leaping, being a greenhorn and novice. The law of sale states that the buyer and seller should both beware (caveat vendor and caveat emptor). Most advertisements for jobs state the location of the job so Cindy should have protested when she was transferred and she should have sought legal intervention in a Labour Relations Court or Tribunal. The Case of Carlill vr Carbolic Smoke Ball in England in the $19^{\text {th }}$ century comes to mind $[16,24]$.

In that landmark case, the advertiser, Carbolic Smoke Ball, promised a service in their advert that their product, carbolic soap, could fulfil its advertised properties to Mrs Carlill (and all who sought a cure for their skin ailments). Mrs Carlill sought remedy in the court of law and the court ruled that the Carbolic Smoke Ball Company had deceived her in particular, and the public in general, because the advert was misleading. Carlill's appeal for legal remedy was upheld. Cindy's employer promised her a job in a specific location but after some years elapsed in her job, she was forced to relocate to an unfriendly location. Cindy, being a woman, she should have negotiated for a shorter stay in her new place in her capacity as a woman, by claiming that she was entitled to her human rights of right of association, movement and to life, liberty, and property. She was not told beforehand that there was going to be a variation in her conditions of service. The employer should have considered her status as a woman. Therefore Cindy could have sued her employers on the grounds that there was no full disclosure of information at the time of signing the contract $[16,24]$.

The offer to treat goes with consideration and acceptance of the offer. If Cindy had known beforehand that there was going to be relocation to a hostile place, she could have considered either not accepting the job offer or she would have asked for higher perquisites. As it was, it would seem that she had bought a pig in a poke and she had been shortchanged. She should have sued her employers for remedies for the mental torture, psychological torture, trauma, and inconvenience caused to her by the transfer. However, she had already signed the contract so it was binding on her and she could not have reneged on it or sought legal remedies. However, it is a legal requirement that parties to a contract should have full disclosure of information prior to signing a contract. It could be conjectured that the contract failed in terms of transparency, full disclosure, and certainty.

On her part, it would seem that she did not do due diligence on her employer's background or else she would have done a hard sell with them by bargaining tough. However, according to $[9,13]$ contracts have implicit aspects 
as not all conditions can be spelt out or predicted, and put in black and white. As it were, there was unequal exchange and unequal power at stake, as the employer had more power than Cindy and Cindy had remedies only in law and under Human Rights Law, as well as participating in industrial action to back demands if there was a trade union at her workplace [9]

$[9,12]$ submitted that the UK Employment Act 1963 as amended in 1996 offers protection to employees who are either wrongfully dismissed or declared redundant. Cindy was not declared redundant neither was she wrongfully dismissed. In any case, the scenario did not state whether Cindy was working either under USA Labour Law or under UK Labour Law. Be that as it may, some academics in Human Resource Management submitted that it is an unwritten law or convention or common law that a person employed for more than three years should be entitled to redundancy rewards or compensation $[4,9,10]$

It is incumbent on firms to pay some severance pay or help with job search or assist in any humane way with a soft rather than a hard landing approach for employees who have lost their jobs [9]. Some contracts make provision for renewal with the proviso that renewal will be the prerogative of the employer and that the employer is not obliged to disclose the reasons for non-renewal of contract of the employee.

Not renewing the contract is not negotiable as it is the right of any employer who plans to substitute labour with artificial intelligence, or machines, or any employer who plans to cut labour costs by downsizing, restructuring, delayering, and right-sizing. Was it that Cindy's skills had become obsolete at that time? If so, could she have been deskilled and taught new skills? Cindy could have walked away with institutional memory and become a competitor to her firm unless there were restrictive clauses in her employment contract of noncompetition to her employers. Cindy's employer should have organised Future Search programmes to empower their staff with entrepreneurial skills for situations like Cindy's imminent termination of contract of employment at the expiry of the contract.

Cindy cut a picture of someone who was highly emotional as she did not go with the flow. Cindy's panicky behaviour of not accepting life as it came showed her to be emotional, judgemental, and not a pragmatist. If she was open-minded, she could have seen some niche in that seemingly difficult location and could have exploited it. As it was, she had a closed mind. Having worked with her employer, and having known the business so well, she could have proposed to be their agent or supplier in the new location whereby she would have entered into a principal-agent relationship which could have given her more negotiating power and leverage. She went to the transfer place and resigned herself mentally that she had been sent to Siberia or a condemned prison, as it were.

When she was told of the transfer, she should have asked for a review or re-negotiation of her contract terms by having a review based on her performance appraisal. If the appraisal showed that she had achieved or exceeded her targets, she should have asked for a salary raise plus other perquisites such as car allowance, risk allowance, and retention allowance. If Cindy was a member of a professional body or Trade Union, she should have used her membership to leverage for better perks [8, 12, 14, 20, 23].

Concerning Cindy's desire to sell her house in the wake of her transfer, she should have known that a house is a fixed asset that appreciates in value over time so she could have put it on mortgage to get a loan and pay back slowly while the loan could have been used to set up her own business. We are not told what her skills were but it can be assumed that she was quite skilful hence her being employed.

Selling the house and its contents for twenty thousand dollars and making a loss of forty thousand dollars was too bad a decision as she could have sat out the depression or recession and waited for a boom year later to sell high. She seemed not to be the adventurous, entrepreneurial or proactive type, and perhaps she was pessimistic and a phlegmatic character, and not a bubbling and optimistic sanguine or an idealist. She should have done deep reflection as a realist. Her xenophobic reaction to her new surroundings painted her as a person who was not open-minded and also one who was judgmental and one without internal locus of control. It is said that every misfortune has a silver lining and every adverse situation is a royal road to success.

'Cindy's personality showed that she was timid and not aggressive. Cindy could have maximized her earnings from the sale of her assets by asset stripping whereby her property could be sold in bits to maximize revenue. Alternatively, she should have sought a property agent to negotiate with him or her to sell for her or better still, she could have negotiated and engaged a finance house to get a loan with her house mortgaged as collateral security.

Cindy had tried unsuccessfully to sell her car and other possessions because she must have used wrong negotiation tactics in her negotiations. She might have made wrong assumptions, and may not have read correctly the body language of potential buyers. She might have been temperamental, not listening enough to have verbal cues, not having experience in using different strategies such as Avoidance, Accommodation, Collaboration, Compromise, and Competition in the bargaining and negotiation process of selling off her properties $[21,26]$.

She might have ignored cultural and contextual factors or she might have had wrong assumptions or wrong attitudes of carrying her ego to the negotiating table or being misinformed and not reading verbal cues. She might have been swayed by high estimation of herself and low estimation of others, and must have had a fixed pie or winlose position of being inflexible.

She might not have been aware of terms such as framing, building golden bridges for other negotiators, using tact and diplomacy, setting the tone by warming up at the initial stages, and she would have lacked empathy and would have focused on her own myopic needs and not being creative enough to expand the pie for everybody to have enough. She may not have explored many multi-media channels such as 
Social Media like Facebook, Instagram, Twitter, WhatsApp groups and LinkedIn to sell her goods to a global audience and close associates.

\section{Findings and Analysis}

\section{Powers and Fears at Play and how Handled}

According to [21] the virtuous circle of employee engagement ensures that there is trust which leads to a winwin situation for both employer and employee. [21] further noted that the nature of employee engagement depends upon the culture and work ethos of an organisation, and their understanding of the psychological contract [10, 21, 22] defined the psychological contract "as a reflection of reciprocal obligations in employment contract in an exchange relationship"[22] Edgar Schein stated that in a contract, each party has a perception, thinking that the other party may have gotten the better of them, leading to mistrust, suspicion, illfeeling and lack of job satisfaction [2, 3] It can be seen that apart from a written or verbal contract, there lurks in the minds of contractees or parties or obligors to a contract their own hidden agendas to cheat each other, especially during the implementation stage of the contract whereby the employee finds out that actually rewards are not commensurate with efforts put in or that there was information asymmetry, or non-disclosure of some information or some hidden costs to the contract. This refers to Stacy Adams Equity theory of motivation.

In motivation theory of Stacy Adams, she referred to this as the Equity theory while V. H. Vroom referred to it as Expectancy theory, and B. F. Skinner called it Reinforcement theory, while Abraham Maslow called it Hierarchy of Needs theory. Adelfer called it Maturity-Immaturity theory and Herzberg as job-context and job-content factors [2, 3, 10, 21]

Power is defined as the capacity to change the changes which if unchanged will remain unchanged. Power is about influence and the influential whereby the powerful ones have control to make others do what they would otherwise not have done on their own. French \& Raven (1972), Max Weber (1880), and Rensis Likert (1965) did studies on sources of power and categorised power into legal or legitimate power, illegitimate power, traditional or hereditary power, expertise power, referent power, personal power or charisma, bureaucratic or positional or institutional power, reward power, coercive or sanctions power, and technological power $[2,4,10,14,18]$.

Cindy had personal power as well as expertise power, and referent power, while her employers had coercive power, reward power, institutional power, exploitative power, referent power, and technical power [21].

When Cindy got the job, she had her own expectations while her employers also had their own expectations. Where both expectations and assumptions do not match or align due to lack of the meeting of the minds (consensus ad idem), there is divergence and perception of being cheated. When Cindy got the job, little did she expect to be transferred to a different terrain, perhaps having stayed put in her job for years, she became docile and complacent.

The perceived difficult terrain and the cultural shock was perhaps due to her own personality or to lack of pre-posting preparation by her employers who should have briefed her and given her some cultural intelligence, and emotional intelligence training. The employer could not have done anything about the difficult terrain because that was an act of God over which they had no control. Every employee should be proactive because no job can give you job security forever.

\section{Discussion}

\section{Non-Negotiable Aspects of Case}

Once an offer of employment contract is accepted and signed, it becomes an instrument which is non-negotiable due to its tenor or meaning of the contract and its tenure or duration.

However, variations to a contract which improve the welfare of the employee are welcome; not variations which reduce the previous endowed conditions as that constitute breach of contract. In a contract of employment, the employer agrees to engage the employee for a fixed period and provide payments and bestow certain privileges on condition that the employee also performs certain prescribed tasks by obeying instructions and working according to the tenor (spirit and letter of the contract) and terms of the contract.

In the scenario, the other non-negotiable part is deployment of Cindy for her to relocate to a new station on transfer. If Cindy did not want to obey to relocate, she would have had to give the minimum notice of separation which is one month in some cases and in some other cases, three months. That is non-negotiable. An employee may lose their salary in lieu of notice $[1,6,7]$.

Cindy agreed to a contract to sell her house and all its contents for 20,000 dollars. That was cheap and a give-away price. That was an unsuccessful negotiation and a sign of desperation because she was going to lose a whopping sum of 40,000 dollars. Her emotion of fear drove her to panic mode and hysteria for her to lose her internal locus of control, bowing to external pressure from friends, colleagues, and even the negotiators to sell her assets cheaply. Cindy lacked confidence and self-belief as she became like a yoyo in the wind.

Perhaps Cindy showed too much anxiety, impatience and fear of the unknown to the potential buyer that weakened her bargaining power or she talked too much about her deplorable condition such that the buyer might have struck fear in her that it would even get worse than that if she dragged her feet and delayed in selling at the time. Cindy therefore entered the negotiation a loser, and already in a weaker position. She should have been composed, and not shown signs of desperation or fear. She should have been courageous, patient, and calculating. Emotion of fear can blind someone and make them make hasty and incorrect decisions.

Cindy could not reverse her decision to sell after she had 
committed herself by word or written agreement. After committing to her desire to sell, that was also non-negotiable because there is what is called meum dictum pactum or my word is my bond in contracts which brokers on the Stock Exchange used to have as their motto. If you go back on your word, you may be sued for breach of contract or you lose your integrity and future goodwill. Thus if the house and contents appreciate in value in a short period of time, Cindy cannot claim extra payments for the appreciation as goods are normally sold on the grounds of as is and where is basis or in situ in loco $[15,16,24]$

Cindy's employers were under no obligation to offer her a job after the expiry of the contract and that is also not negotiable. Being deployed on the job is also not negotiable, especially if it is a contract of employment and not a contract for the provision of outsourced services [10] Cindy was not an independent contractor but a full time employee on fixed term contract with her employer so she was neither entitled to redundancy pay nor to unemployment pay $[4,8,11,19]$.

\section{Conclusion}

In conclusion, the case study had examined a scenario involving employment contract, what a valid contract is, which aspects of Cindy's negotiations were successful and which were not successful. Cindy went into panic mode when her contract was ending and she desperately tried to sell her assets such as her house, car, and other personal belongings.

She could have taken unemployment insurance or used the funds from her end of contract gratuity to set up an enterprise of her own to be her own employer and boss. She had a closed mind and was not much of a risk-taker. Finally, Cindy should have re-negotiated some aspects of her contract to have either given her a chance of extension or renewal of the contract. Her transfer called into question many issues, some HRM-related, some legal, and others personal. This article has reviewed concepts of contracts, negotiations, power sources, motivation, and other issues.

\section{References}

[1] ACAS Written statements of terms and conditions of employment

http://www.acas.org.uk/index.aspx?articleid $=3970$

[2] Armstrong, M. \& Taylor, S. (2017) Armstrong's Handbook of Human Resource Management Practice London: Kogan Page.

[3] Armstrong, M. (1993) A Handbook of Personnel Management

[4] Beardwell, J. \& Thompson, A. (2017) A Human Resource Management- A Contemporary Approach London: Pearson Learning

[5] Bedard, G. (n. d.) Welcome to Negotiation and Contract Management-NVIT [Online].

[6] Byars, L. L. \& Rue, L. W. (1997) Human Resource Management $\left(5^{\text {th }}\right.$ ed.) Boston: Irwin
[7] Capelli, P. \& Keller, J. (2014) Talent Management: Conceptual Approaches and Practical Challenges Annual Review of Organizational Psychology and Organizational Behavior 1 Vol. 1 pp. 308-331.

[8] CEO World. biz (2018) How to renegotiate your employment contract when you have achieved success [Online] https://ceoworld.biz/2018/02/01/how-to-renegotiate-your-ceoemployment-contract-when-you-have-achieved-success

[9] Cole, G. A. (2002) Personnel and Human Resource Management $\left(5^{\text {th }}\right.$ ed.) London: Cengage Learning.

[10] Cole, G. A. (2004) Management Theory and Practice $\left(6^{\text {th }}\right.$ ed.) Singapore: Thomson Learning.

[11] Francis, K. A. (2019) Terms \& Conditions of an Employment Contract - Small Business [Online] Retrieved from Chron.com, http://smallbusiness.chron.com/terms-conditionsemployment-contract-4784.html. 15 March 2019.

[12] Gennard, J. \& Judge, G.(2012) Employee Relations (4 ${ }^{\text {th }}$ ed.) London: CIPD. Key, S. (2015) 9 Ways to negotiate a contract like a boss [Online] Entrepreneur Franchise 500.

[13] Harvard Business Review (HBR) (2016) How to Renegotiate a Bad Deal Program on Negotiation (PON) at Harvard Law School Retrieved from https://www.pon.harvard.edu./.

[14] Heneman, Schwab, Fossum (1995) Personnel/Human Resource Management New York, N.Y.: Irwin

[15] Key, S. (2015) 9 Ways to negotiate a contract like a boss [Online] Entrepreneur Franchise 500.

[16] LawTeacher (2018) Main Elements Constituting a Valid Contract https://www.lawteacher.net/free-law-essays/contractlaw/main-elements-constituting-a-valid-contract-contract-lawessay.php

[17] Lawyers Weekly.com (n. d.) Five things to think about when signing or re-negotiating your employment contract [Online] https://www.lawyersweekly.com.au/opinion/23569-fivethings-to-think-about-when-signing-or-re-negotiating-youremployment-contract.

[18] Lazear, E. P. \& Gibbs, M. (2015) Personnel Economics in Practice New York, N. Y.: Wiley.

[19] Mansfield, G., Banerjee, L. \& Brown, D. (2017) Blackstone's Employment Practice ( $9^{\text {th }}$ ed.) Oxford: OUP.

[20] Morrison, E. (2014) Employee Voice and Silence Annual Review of Organizational Psychology and Organizational Behavior

[21] Mullins, L. J. \& Christy, G. (2010) Management and Organisational Behaviour (11 ${ }^{\text {th }}$ ed.) Harlow, Edinburgh: Pearson Education Limited.

[22] Perkins, S. \& White, G. (2009) Employee Reward London: CIPD.

[23] Rose, E. (2008) Employment Relations London: FT Prentice Hall.

[24] Teacher, Law (November 2013). Main Elements constituting A Valid Contract. Retrieved from https://www.lawteacher.net/free-law-essays/contractlaw/main-elements-constituting-a-valid-contract-contract-lawessay.php?vref $=1$ 
[25] Torrington, D., Hall, L., Taylor, S. and Atkinson, C. (2011) Human Resource Management ( $8^{\text {th }}$ ed.). London: Pearson Education.

[26] Ury, W. (1993) Getting Past No: Negotiating your way from
Confrontation to Cooperation (Revised Edition) New York: Bantam Books.

[27] Weightman, J. (2004) Managing People (2 ${ }^{\text {nd }}$ ed.) London: CIPD chp. 13 and 14. 